\title{
EFFECT OF HOLDING TIME AT STABILIZATION ANNEALING ON PROPERTIES OF 08CH18N10T AUSTENITIC STAINLESS STEEL
}

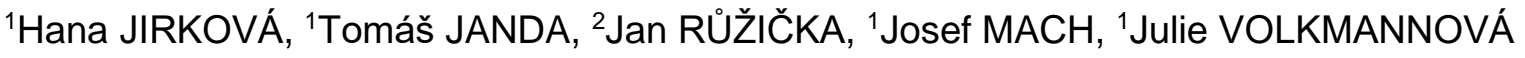 \\ 'University of West Bohemia, RTI - Regional Technological Institute, Pilsen, Czech Republic, EU, \\ hstankov@rti.zcu.cz, jandat@rti.zcu.cz,machi@rti.zcu.cz,volkmann@rti.zcu.cz \\ 2ŠKODA JS a.s., Orlík 266/15, Pilsen, Czech Republic, EU, Jan.Ruzicka@skoda-js.cz
}

https://doi.org/10.37904/metal.2020.3498

\begin{abstract}
Titanium-stabilized austenitic stainless steel $08 \mathrm{Ch} 18 \mathrm{~N} 10 \mathrm{~T}$ is often used in nuclear power facilities due to its favourable properties. Many parts of the primary circuit of VVER 440 and VVER 1000-type nuclear power plants are manufactured of this steel. This means that the material must possess very good corrosion resistance and thermal stability of structure. Yield strength of at least $177 \mathrm{MPa}$ at $350{ }^{\circ} \mathrm{C}$ is required. Heat treatment of this steel comprises several important stages which affect the resulting mechanical properties. In particular, the solution and stabilization annealing after forging or rolling are time and energy consuming. Therefore, various ways to optimize these processes are being sought.
\end{abstract}

A combination of solution annealing at $1020{ }^{\circ} \mathrm{C}$ for 15 and 30 minutes and stabilization annealing at $720{ }^{\circ} \mathrm{C}$ with dwell of 2.5 hours to 15 hours was tested on $08 \mathrm{Ch} 18 \mathrm{~N} 10$ steel samples. The aim was to establish the effects of stabilization annealing and solution annealing times on mechanical properties. Longer solution annealing has a pronounced effect on the reduction of scatter in mechanical properties. All annealing routes led to yield strengths at $350{ }^{\circ} \mathrm{C}$ higher than $200 \mathrm{MPa}$ and tensile strengths of more than $380 \mathrm{MPa}$.

Keywords: $08 \mathrm{Ch} 08 \mathrm{~N} 10 \mathrm{~T}$, solution annealing, stabilization annealing

\section{INTRODUCTION}

The purpose of the heat treatment of austenitic stainless steels is to obtain desired mechanical and corrosion properties and, where relevant, reduce internal stresses. Thanks to their creep resistance and resistance to intergranular corrosion, they are often used in applications involving elevated temperatures. In WWER nuclear plants, one prominent representative of this class of steels is the GOST 5632 grade. Its properties comply with the former Soviet design code for nuclear facilities PNAE-G. Its structure is stabilized with titanium. Its alternative designation is 08Ch18N10T. The properties of this steel strongly depend on titanium carbide and carbonitride precipitates which form during stabilization annealing [1]. The purpose of stabilization with titanium is to prevent precipitation of $\mathrm{Cr}_{23} \mathrm{C}_{6}$ carbides, which deplete the matrix of chromium [2,3]. Furthermore, these carbides precipitating on grain boundaries reduce the material resistance to intergranular corrosion. In steels of this type, this difficulty is eliminated by stabilization annealing at $845-950{ }^{\circ} \mathrm{C}[4,5]$.

The full heat treatment sequence for this steel consists of solution and stabilization annealing. Solution annealing is performed in accordance with specifications in the temperature ranges from 1020 to $1100^{\circ} \mathrm{C}[1,2]$ or from 1100 to $1150{ }^{\circ} \mathrm{C}$ for 1 to 5 hours [6-8]. A temperature of $1200{ }^{\circ} \mathrm{C}$ is used only exceptionally [8]. The subsequent stabilization annealing leads to increased mechanical properties, particularly hot yield strength. It is performed at the temperatures from 600 to $850^{\circ} \mathrm{C}$ with dwelling times up to tens of hours $[1,6]$. The task of treating the $08 \mathrm{Ch} 18 \mathrm{~N} 10 \mathrm{~T}$ steel for nuclear power applications correctly is rather complex. The previous treatment history needs to be known as well because it governs the outcomes of both solution and stabilization annealing. 
The difficulty with heat treating this steel grade is the long times and the amount of energy required. This is why alternative optimum combinations are sought, involving solution annealing and stabilization annealing with shorter times, particularly in the latter, while achieving compliance with prescribed mechanical properties. In this paper, description is given of the effects of the stabilization annealing time on hot yield strength in 08Ch18N10T steel. Stabilization annealing followed after solution annealing with different annealing times.

\section{MATERIALS AND METHODS}

\subsection{Experimental material}

The experiments outlined below were performed on $08 \mathrm{CH} 18 \mathrm{~N} 10 \mathrm{~T}$ steel (Table 1). In addition to inclusion content, the microstructure of this steel is monitored for the content, morphology and distribution of titanium carbonitrides. The relative levels of carbon and titanium are important as well. There is a specified value of hot yield strength for use in WWER reactor facilities: at $350{ }^{\circ} \mathrm{C}$ it should be no less than $177 \mathrm{MPa}$. An equivalent grade is AISI 321 according to ASTM/ASME (the designation in EN standards is X6CrNiTi18-10 (1.4541)). However, the minimum prescribed hot yield strength for this equivalent grade is less than the requirement for WWER facilities.

Table 1 Chemical composition of 08Ch18N10T steel in the present experiment (wt\%)

\begin{tabular}{|c|c|c|c|c|c|c|c|c|c|c|c|c|c|c|}
\hline $\mathbf{C}$ & $\mathbf{C r}$ & $\mathbf{N i}$ & $\mathbf{T i}$ & $\mathbf{M n}$ & $\mathbf{S i}$ & $\mathbf{P}$ & $\mathbf{S}$ & $\mathbf{C u}$ & $\mathbf{M o}$ & $\mathbf{V}$ & $\begin{array}{c}\mathbf{N} \\
(\mathbf{p p m})\end{array}$ & $\mathbf{W}$ & Co & $\begin{array}{c}\mathbf{H} \\
(\mathbf{p p m})\end{array}$ \\
\hline 0.05 & 17.75 & 10.05 & 0.43 & 1.8 & 0.52 & 0.024 & 0.014 & 0.1 & 0.08 & 0.11 & 120 & 0.03 & 0.02 & 2.4 \\
\hline
\end{tabular}

The steel was supplied as heat-treated bars $90 \mathrm{~mm}$ in diameter. The heat treatment route comprised solution annealing at $1020{ }^{\circ} \mathrm{C}$ for 110 minutes and stabilization annealing at $720{ }^{\circ} \mathrm{C}$ for 600 minutes. The bars were sectioned by waterjet cutting into samples $45 \times 20 \times 110 \mathrm{~mm}$ in size. These were then experimentally heattreated using various parameters.

\subsection{Heat treatment}

The treatment was performed in an air furnace. The solution annealing temperature was $1020{ }^{\circ} \mathrm{C}$. As the samples were much smaller than the bars, shorter times at temperature were used: 15 minutes and 30 minutes after the temperature in the entire sample became homogeneous. The temperature was measured with a $\mathrm{K}$ type thermocouple placed in a hole drilled in the sample to a depth of $10 \mathrm{~mm}$. The annealing temperature could thus be monitored, as well as the time required for bringing the sample to temperature. After solution annealing, the samples were quenched in water. Stabilization annealing at $720{ }^{\circ} \mathrm{C}$ involved five different times from 2.5 hours to 15 hours. The samples then cooled in air. As with solution annealing, the ramp time for reaching the annealing temperature was measured using thermocouple.

\subsection{Methods of evaluation}

The microstructures of the as-received material (initial state) and the treated samples were documented using an Olympus optical microscope (OM). Detailed examination, including a chemical analysis using EDS, was performed in Zeiss EVO MA and Tescan Easy Probe scanning electron microscopes (SEM). Mechanical properties were determined by tensile testing at room temperature (RT) according to EN ISO 6892-1 and at $350^{\circ} \mathrm{C}$ in accordance with EN ISO 6892-2. The diameter and gauge length of the test pieces were $\mathrm{d}=10 \mathrm{~mm}$ and $l_{0}=50 \mathrm{~mm}$, respectively. In each case, two samples were used for tensile testing, one located near the surface of the original bar (referred to as "edge") and one from the central region ("centre") because austenite grain size was expected to vary across the bar's cross section. From each sample, two tensile test pieces were made and specimens for microstructure characterization were taken. Hence, the impact of the treatment as 
well that of the location within the original bar to be assessed. In addition, hardness was measured and reported using HV10 hardness number.

\section{RESULTS AND DISCUSSION}

\subsection{Microstructure analysis}

The microstructure of as-received bars of $90 \mathrm{~mm}$ diameter was examined on longitudinal and transverse cross sections. It contained equiaxed austenite grains with distinct slip bands, twins and intermetallic phases, including titanium nitrides, carbides and carbonitrides, and a small amount of delta ferrite (Figure 1). The macrostructure was non-uniform on the cross section, consisting of coarser and finer austenite regions, with the grain size increasing slightly toward the centre of the bar. This was confirmed by grain size measurement using the intercept method according to ASTM A112. In the "edge" sample, the grain size was 44 and $54 \mu \mathrm{m}$ on the longitudinal and transverse cross sections, respectively. In the "centre" sample, it was 63 and $60 \mu \mathrm{m}$ on the longitudinal and transverse cross sections, respectively (Figure 2). Solution annealing for 15 and 30 minutes caused no appreciable changes in the microstructure (Figure 3). The austenite grain size remained substantially unchanged as well (Figure 2).

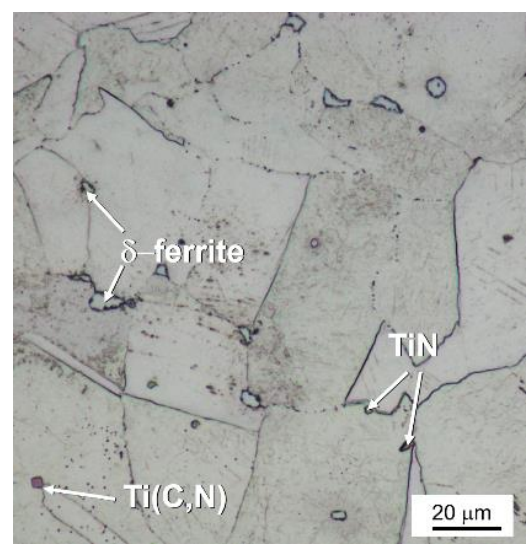

Figure 1 Microstructure of asreceived bars, "centre", optical micrograph

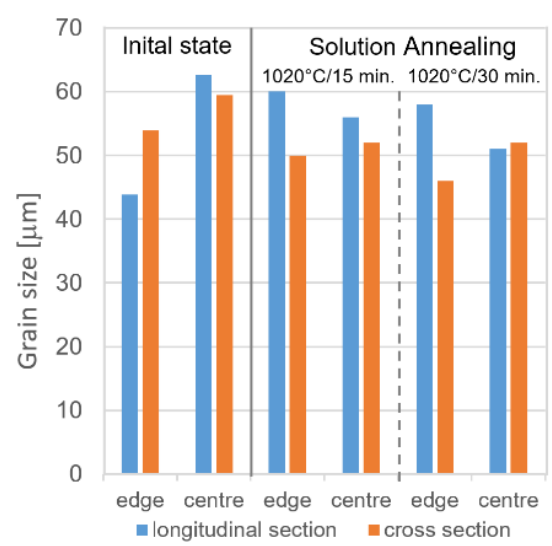

Figure 2 Grain size of as-received material (initial state) and the solution-annealed samples

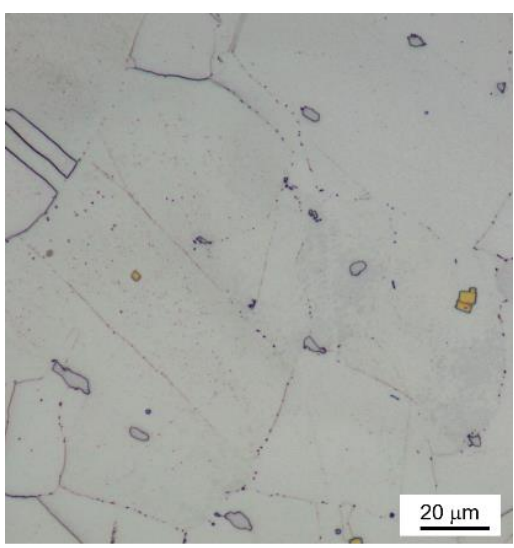

Figure 3 Optical micrograph of solution annealed material $1020^{\circ} \mathrm{C} / 30$ minutes
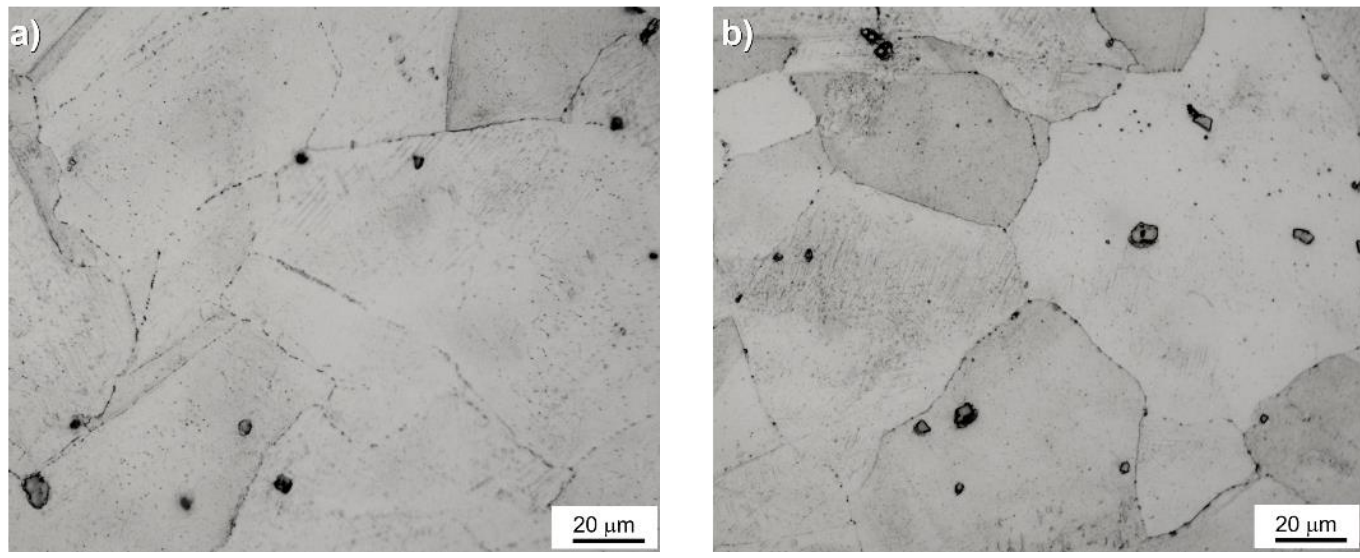

Figure 4 Micrographs of stabilization-annealed material, $720^{\circ} \mathrm{C}$ (after solution annealing 1020 ${ }^{\circ} \mathrm{C} / 30$ minutes): a) time at temperature: 2.5 hours, b) 15 hours 
The variations with the location within the bar could be attributed to the non-uniformity of the initial condition of the material. Yet, stabilization annealing led to minute structural changes. Precipitates became coarser and a dispersion of fine particles emerged within austenite grains (Figure 4).

\subsection{Mechanical testing}

Mechanical tests were performed at room temperature and at $350{ }^{\circ} \mathrm{C}$. The requirement for parts of WWERtype nuclear facility made of this steel is hot yield strength (at $350{ }^{\circ} \mathrm{C}$ ) of no less than $177 \mathrm{MPa}$. Testing was performed on "edge" samples located near the surface of the original bar and "centre" samples close to the axis of the bar.

The ultimate strength at room temperature in "edge" samples was $573 \mathrm{MPa}$. This was higher than in the "centre": $560 \mathrm{MPa}$. Hot yield strength in "edge" and "centre" samples was $337 \mathrm{MPa}$ and $335 \mathrm{MPa}$, respectively. These values correlate with grain size which was finer near the bar's surface than in the centre (Figure 5). Given the size and non-uniformity of the structure across the cross section, the differences of $13 \mathrm{MPa}$ in ultimate strength and $2 \mathrm{MPa}$ in yield strength are negligible and have no practical impact. Testing at $350{ }^{\circ} \mathrm{C}$ led to an ultimate strength of $410 \mathrm{MPa}$, yield strength of $276 \mathrm{MPa}$ and elongation of $26 \%$ (Figure 5). After solution annealing, the ultimate strength and yield strength were lower. The ultimate strength at room temperature was $30 \mathrm{MPa}$ lower after annealing for 15 minutes. Annealing for 15 minutes caused yield strength to decrease from $336 \mathrm{MPa}$ to $270 \mathrm{MPa}$. The 30-minute annealing led to a value of $293 \mathrm{MPa}$. Elongation rose by approximately 5 percentage points. The likely causes of this softening include dissolution of fine intermetallic particles and reduction in dislocation density. Similar trends were found by tests at $350{ }^{\circ} \mathrm{C}$. After solution annealing, the yield strength decreased to 207 and $230 \mathrm{MPa}$. In both cases, the criterion of the minimum value of $177 \mathrm{MPa}$ was met.
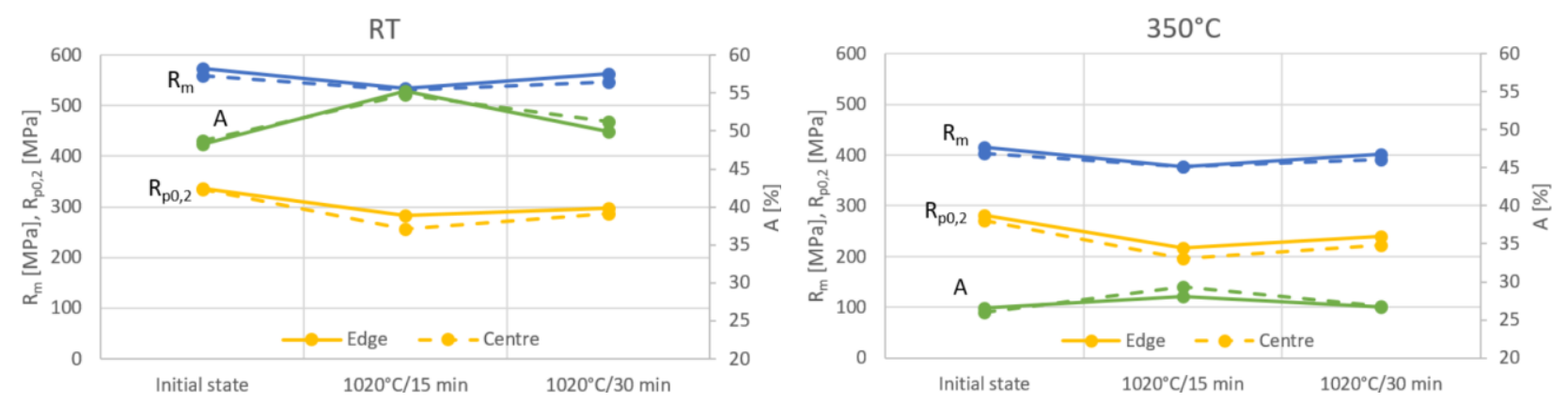

Figure 5 Mechanical properties of as-received material (initial state) and solution-annealed samples tested at $\mathrm{RT}$ and $350^{\circ} \mathrm{C}$

Testing at room temperature after stabilization annealing at $720^{\circ} \mathrm{C}$ revealed that longer times at temperature lead to higher ultimate strength and yield strength. The impact of the preceding step, i.e. solution annealing at $1020^{\circ} \mathrm{C}$ for 15 and 30 minutes, was assessed as well. After 15-minute solution annealing, longer times of stabilization annealing at $720{ }^{\circ} \mathrm{C}$ led to higher ultimate strengths. Expressed numerically, $540 \mathrm{MPa}$ was obtained after 2.5-hour annealing, whereas $560 \mathrm{MPa}$ was found after 15 hours (Figure 6). Yield strength showed the same trend. This means that longer times at $720^{\circ} \mathrm{C}$ resulted in increased yield strength: from $295 \mathrm{MPa}$ to $330 \mathrm{MPa}$. By contrast, elongation decreased slightly with increasing time at temperature: from approximately $54 \%$ to $51 \%$.

Solution annealing with longer time at temperature, 30 minutes, combined with the subsequent stabilization annealing led to ultimate strengths from 541 to $545 \mathrm{MPa}$. Yield strengths were between 294 and $306 \mathrm{MPa}$ (Figure 6). Elongation values were around $53 \%$, regardless of the length of stabilization annealing. The difference between the "edge" and "centre" samples was minute: under $10 \mathrm{MPa}$. 

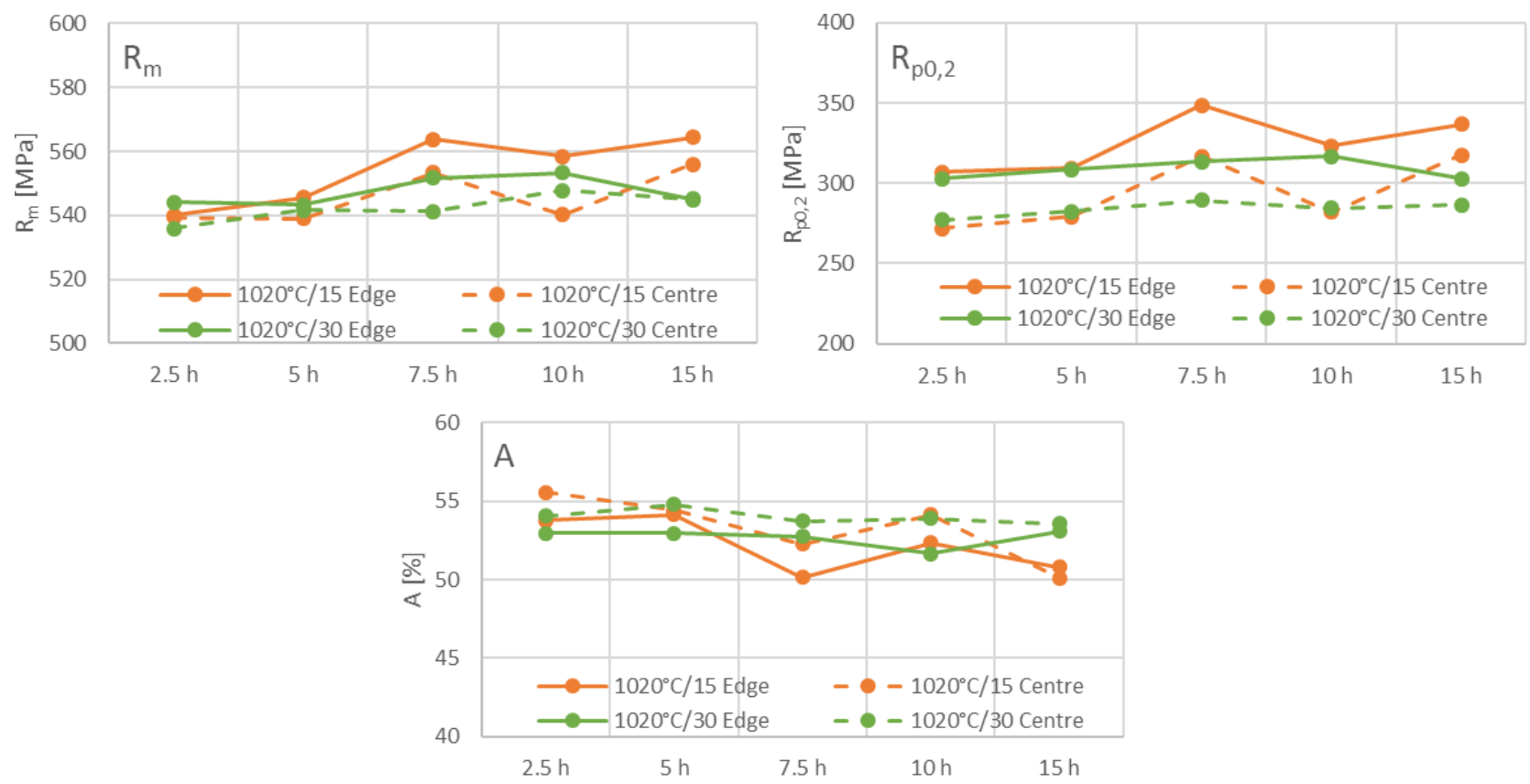

Figure 6 Results of tensile testing at room temperature for stabilization-annealed material and different times at temperature

Tensile testing at $350{ }^{\circ} \mathrm{C}$ revealed no substantial impact of the time at stabilization annealing temperature (Figure 7). Slight increases were found after combinations with 15-minute solution annealing. With longer annealing times, the ultimate strength rose from $390 \mathrm{MPa}$ to $404 \mathrm{MPa}$ and the yield strength from $238 \mathrm{MPa}$ to $260 \mathrm{MPa}$. When the preceding solution annealing time was 30 minutes, there was no change in these values with stabilization annealing time. In all the cases, the yield strength was higher than the specified minimum of $177 \mathrm{MPa}$. Longer solution annealing times clearly led to more consistent properties after stabilization annealing. After those routes which involved the longer solution annealing time, there were no dramatic variations between specimens.
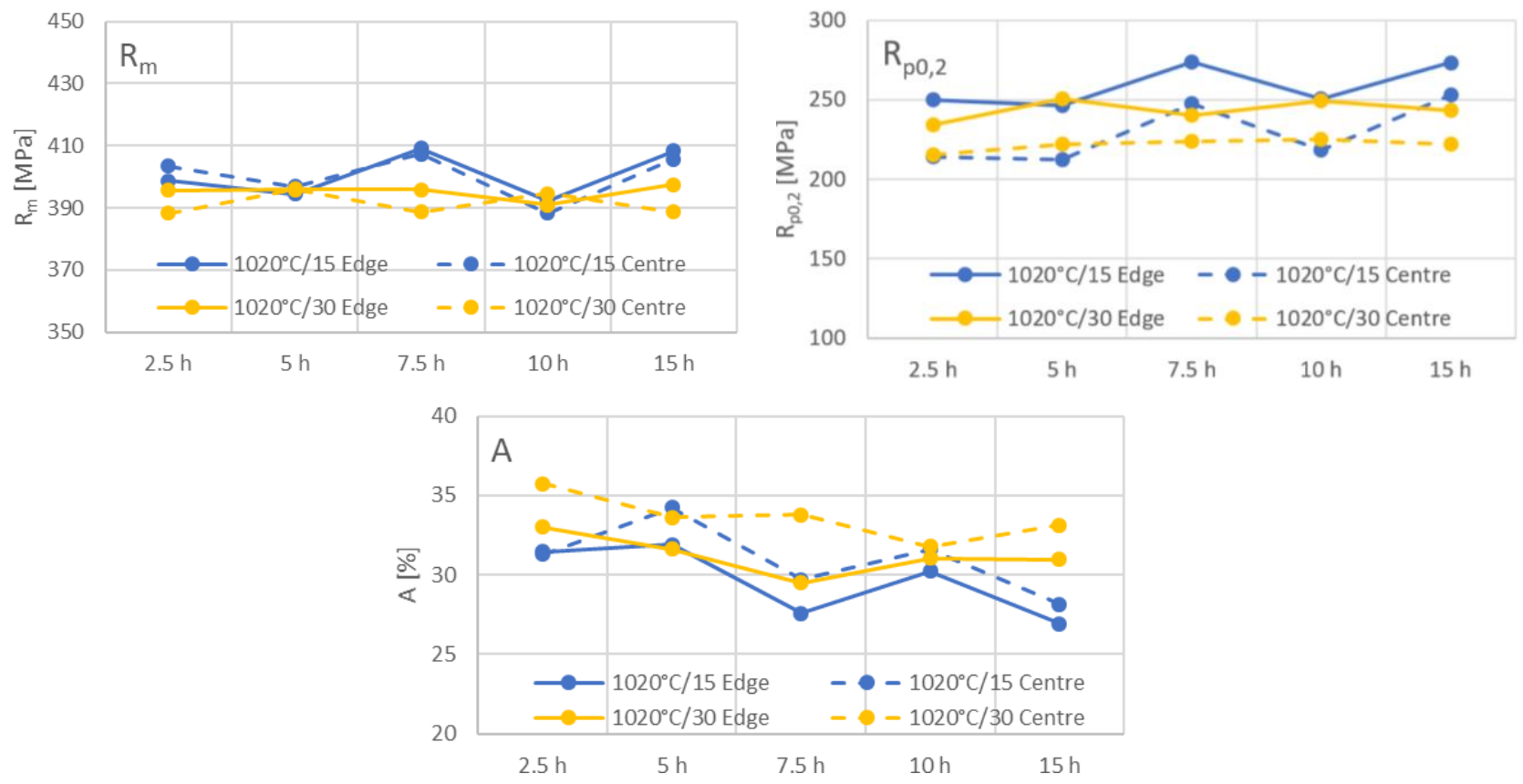

Figure 7 Results of tensile testing at $350{ }^{\circ} \mathrm{C}$ for stabilization-annealed material and different times 


\section{CONCLUSION}

Austenitic stainless steel grade $08 \mathrm{CH} 18 \mathrm{~N} 10 \mathrm{~T}$ stabilized with titanium was used to investigate the effect of stabilization annealing times at $720^{\circ} \mathrm{C}$ on mechanical properties. Stabilization annealing was preceded by solution annealing at $1020^{\circ} \mathrm{C}$ for 15 minutes or 30 minutes and by water quenching. The dwelling times at the temperature of stabilization annealing were from 2.5 to 15 hours.

The resulting microstructure consisted of equiaxed austenite grains with numerous annealing twins, delta ferrite grains and intermediate phase particles $(\mathrm{Ti}(\mathrm{C}, \mathrm{N}), \mathrm{TiN})$. These phases were found within austenite grains as well as at their boundaries. The ultimate strength and yield strength at room temperature increased slightly with time at the stabilization annealing temperature of $720^{\circ} \mathrm{C}$. Notably higher values were obtained after routes with 15-minute solution annealing. The ultimate strength was $540-560 \mathrm{MPa}$ at room temperature and $391-$ $404 \mathrm{MPa}$ at $350{ }^{\circ} \mathrm{C}$. The yield strength ranged from $295 \mathrm{MPa}$ to $330 \mathrm{MPa}$ at room temperature and from $238 \mathrm{MPa}$ to $267 \mathrm{MPa}$ at $350{ }^{\circ} \mathrm{C}$. Elongation $\mathrm{A}_{5.65}$ was $51 \%-54 \%$ at room temperature and $27 \%$ to $34 \%$ at $350{ }^{\circ} \mathrm{C}$. Results without dramatic variation between specimens were obtained with the longer solution annealing time. Longer times at $1020^{\circ} \mathrm{C}$ produce more uniform structure and consistent results.

\section{ACKNOWLEDGEMENTS}

This research was funded by the Technology Agency of the Czech Republic under the project TJ02000274 ,Determination of the principles and processes taking place during the stabilization annealing of austenitic stainless steels used in nuclear power".

\section{REFERENCES}

[1] MOURA, V., KINA, A.Y., TAVARES, L.S.S M., LIMA, D., MAINIER, F.B. Influence of stabilization heat treatments on microstructure, hardness and intergranular corrosion resistance of the AISI 321 stainless steel. Journal of Materials Science. 2008, vol. 43, no. 2, pp. 536-540.

[2] KANEKO, K., FUKUNAGA, T., YAMADA, K., NAKADA, N. KIKUCHI, M., SAGHI, Z., BARNARD, J.S., MIDGLEY, P.A. Formation of M23C6-type precipitates and chromium-depleted zones in austenite stainless steel. Scripta Materialia. 2011, vol. 65, no. 6, pp.509-512.

[3] PODANY, P., MARTÍNEK, P., NACHÁZEL, J., BALCAR, M. Heat Treatment of Reactor Vessel Steel 08Ch18N10T. In: MS\&T 2012: Materials Science and Technology Conference and Exhibition 2012. NY: Materials Science and Technology (MS\&T), 2012, pp. 1036-1043.

[4] ROSENBERG, S.J., DARR, J.H. Stabilization of austenitic stainless steel. Journal of Research of the National Bureau of Standards. 1948, vol. 40, no. 4, pp. 321-338.

[5] George E. Encyclopedia of iron, steel and their alloys - vol 5. 2016

[6] PARDO, A., MERINO, M.C., COY, A.E., VIEJO, F., CARBONERAS, M., ARRABAL, R. Influence of Ti, C and N concentration on the intergranular corrosion behaviour of AISI $316 \mathrm{Ti}$ and 321 stainless steels. Acta Materialia. 2007, vol. 55, no. 7, pp. 2239-2251.

[7] KINA, A.Y, SOUZA, V.M., TAVARES, S.S.M., SOUZA, J.A., DE ABREU, H.F.G. Influence of heat treatments on the intergranular corrosion resistance of the AISI 347 cast and weld metal for high temperature services. Journal of Materials Processing Technology. 2008, vol. 199, no. 1, pp. 391-395.

[8] PADILHA, A.F., PLAUT, R.L., RIOS, P.R. Annealing of Cold-worked Austenitic Stainless Steels. ISIJ International. 2003, vol. 43, no. 2, pp. 135-143.

[9] REZAEI, H.A., GHAZANI, M.S., EGHBALI, B. Effect of post deformation annealing on the microstructure and mechanical properties of cold rolled AISI 321 austenitic stainless steel. Materials Science and Engineering A. 2018, vol. 736, no. 8, pp. 364-374. 